\title{
Vitamin A and iron supplementation of Indonesian pregnant women benefits vitamin A status of their infants
}

\author{
Marjanka K. Schmidt ${ }^{1,2}$, Siti Muslimatun ${ }^{1,2}$, Clive E. West ${ }^{1,3} *$, Werner Schultink ${ }^{4}$ and \\ Joseph G. A. J. Hautvast ${ }^{1}$ \\ ${ }^{1}$ Division of Human Nutrition and Epidemiology, Wageningen University, The Netherlands \\ ${ }^{2}$ SEAMEO TROPMED Regional Center for Community Nutrition, University of Indonesia, Jakarta, Indonesia \\ ${ }^{3}$ Department of Gastroenterology, University Medical Center Nijmegen, The Netherlands \\ ${ }^{4}$ UNICEF, New York, NY, USA \\ (Received 1 February 2001 - Revised 11 June 2001 - Accepted 17 July 2001)
}

\begin{abstract}
Many Indonesian infants have an inadequate nutritional status, which may be due in part to inadequate maternal nutrition during pregnancy. This study was designed to investigate whether infant nutritional status could be improved by maternal vitamin A and Fe supplementation during gestation. Mothers of these infants from five villages had been randomly assigned on an individual basis, supervised and double-blind, to receive supplementation once weekly from approximately 18 weeks of pregnancy until delivery. Supplementation comprised $120 \mathrm{mg} \mathrm{Fe}$ and $500 \mu \mathrm{g}$ folic acid with or without 4800 retinol equivalent vitamin A. Mothers of infants from four other villages who participated in the national Fe and folic acid supplementation programme were also recruited; intake of tablets was not supervised. Anthropometric and biochemical parameters of infants and their mothers were assessed approximately 4 months after delivery. Infants of mothers supplemented with vitamin A plus Fe had higher serum retinol concentrations than infants of mothers supplemented with $\mathrm{Fe}$ alone. However, the proportion of infants with serum retinol concentrations $<0.70 \mu \mathrm{mol} / \mathrm{l}$ was $>70 \%$ in all groups. Maternal and infant serum retinol concentrations were correlated. Fe status, weight and length of infants were similar in all groups. Fe status of girls was better than that of boys, but boys were heavier and longer. We conclude that supplementation with vitamin A in conjunction with Fe supplementation of women during pregnancy benefits vitamin A status of their infants. However, considering the large proportion of infants with marginal serum retinol concentrations, it may still be necessary to increase their vitamin A intake.
\end{abstract}

Infant nutritional status: Vitamin A: Iron: Supplementation during pregnancy

In Indonesia many infants have an inadequate nutritional status as shown by the high prevalence of micronutrient deficiencies, underweight and stunting (Administrative Committee on Coordination/Sub-Committee on Nutrition, 2000). Low nutrient stores and growth retardation of infants may partly be caused by inadequate nutrition of their mothers during pregnancy (Waterlow \& Schürch, 1994; Frongillo, 1999). A large proportion of Indonesian pregnant women suffer from Fe deficiency anaemia and marginal vitamin A deficiency (Suharno et al. 1992; Kosen et al. 1998; ACC/SCN, 2000).

Adequate maternal vitamin A status during pregnancy is important for the development of the fetus and for sufficient levels of vitamin A in breast milk (Underwood,
1994). The relationship between the vitamin A status of pregnant women and that of their newborn infants is indicated by associations of serum retinol levels during pregnancy with fetal liver retinol concentrations and by the high correlation of vitamin A concentrations between cord and maternal serum (Shah \& Rajalakshmi, 1984; Shah et al. 1987). In addition, vitamin A supplementation of pregnant women has been shown to increase cord levels of vitamin A (Panth et al. 1990). Vitamin A intake and status in the third trimester of pregnancy have been found to affect concentrations of vitamin A in breast milk (Ortega et al. 1997).

$\mathrm{Fe}$ deficiency anaemia during pregnancy is associated with a higher risk of low birth weight and preterm delivery

\footnotetext{
Abbreviations: RE, retinol equivalent; sTfR, soluble transferrin receptor.

* Corresponding author: Dr Clive E. West, fax +31 317 483342, email Clive.West@staff.nutepi.wau.nl
} 
(Scholl \& Hediger, 1994). In addition, evidence is accumulating that maternal Fe deficiency in pregnancy reduces fetal Fe stores and this may influence development during the postnatal period (Allen, 2000). In a placebocontrolled study in Niger, Fe supplementation during pregnancy improved infant length and Apgar scores at birth, and serum ferritin concentration 3 months after birth (Preziosi et al. 1997). Under conditions of poor diet quality, Fe alone may not be effective in correcting Fe deficiency anaemia during pregnancy (Yip, 2000). Vitamin A supplementation has been found to improve haemoglobin concentrations of pregnant women (Panth et al. 1990; Suharno et al. 1993) and vitamin A plus Fe supplementation to benefit the Fe status of children (Mejia \& Chew, 1988). Roodenburg et al. (1996) confirmed the benefit of vitamin A for $\mathrm{Fe}$ status in a study in rats and suggested that mobilisation of $\mathrm{Fe}$ was improved by vitamin $\mathrm{A}$ supplementation.

In Indonesia $\mathrm{Fe}$ supplementation during pregnancy is standard practice, and therefore it is not ethical to conduct a study in which pregnant women are not provided with $\mathrm{Fe}$ (Yip, 2000). However, compliance in the governmental programme is low and we found that supervised weekly Fe supplementation performed similarly to the ongoing $\mathrm{Fe}$ supplementation programme with regard to improving maternal Fe status during pregnancy (Muslimatun et al. 2001). Considering the adverse effects of Fe deficiency on the mental and motor development of infants (Nokes et al. 1998) it is important to assess the impact of any new Fe supplementation regime on infant Fe status.

We hypothesised that improving the vitamin $\mathrm{A}$ and $\mathrm{Fe}$ status of pregnant women would lead to an improvement in Fe status, vitamin A status, length and weight of their infants after birth. The present study was designed to investigate whether infant nutritional status could be improved by weekly supplementation of their mothers during pregnancy with vitamin $\mathrm{A}$ and $\mathrm{Fe}$.

\section{Materials and methods Study design}

The present study was carried out in infants from nine rural villages in Leuwiliang subdistrict, Bogor district, West Java, Indonesia. Mothers of these infants had been supplemented with $\mathrm{Fe}$ and folic acid, either with or without vitamin A, during pregnancy or had access to Fe plus folic acid tablets through the ongoing government programme. Explanation of the study had been given to the women at enrolment and only women who gave written informed consent

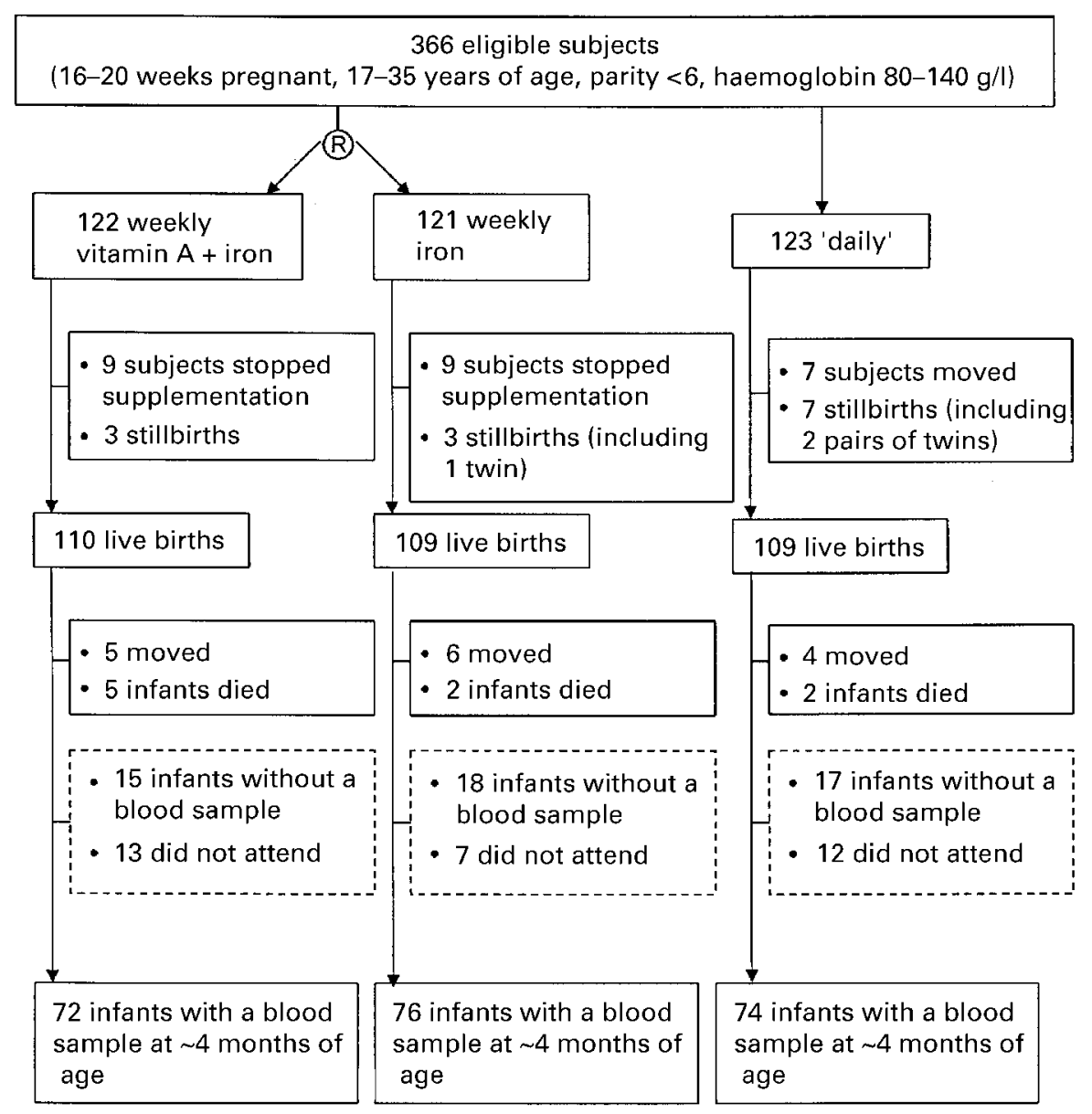

Fig. 1. Study profile. Indonesian women, from nine villages, at approximately 17 weeks of pregnancy were recruited for three treatment groups: those receiving two tablets weekly containing $60 \mathrm{mg}$ ferrous sulfate and $250 \mu \mathrm{g}$ folic acid ('iron') with or without 2400 retinol equivalent vitamin A, and the 'daily' group, who had free access to iron tablets from the Indonesian governmental health services. 
participated. The research proposal was approved by the Ministry of Health Indonesia and the ethical committees of the medical faculty at the University of Indonesia and Wageningen University.

Initially 366 women were enrolled in the study (Fig. 1). A sample size of 120 women per group had been chosen to allow for $50 \%$ drop-out during the study period (Muslimatun et al. 2001). The present article reports the effect of supplementation on the nutritional status of infants at approximately 4 months of age. The results of the effect of supplementation with $\mathrm{Fe}$ and vitamin A during pregnancy on biochemical status near term, including details of the study design, have been published elsewhere (Muslimatun et al. 2001). Briefly, women, who were 16-20 weeks pregnant, aged 17-35 years and with parity $<6$, from five villages were randomly assigned on an individual basis to double-blind, weekly supplementation until delivery. Supplementation consisted of two tablets each containing $60 \mathrm{mg} \mathrm{Fe}$ as ferrous sulfate and $250 \mu \mathrm{g}$ folic acid with or without 2400 retinol equivalent (RE) vitamin A. WHO guidelines (World Health Organization, 1998) allow a maximum weekly dose of $7500 \mathrm{RE}$. The intention was to supplement pregnant women with 6000 RE per week, based on advice of the Indonesian Ministry of Health. However, owing to losses during storage, vitamin A supplementation was found to be 4800 RE weekly. Tablet intake was supervised by volunteer health workers and monitored by field assistants. Health personnel and participants received clear instructions in order to avoid additional Fe tablet intake. The average period of supplementation in these 'weekly' groups was 20 weeks; thus, mothers had taken about forty tablets. Women from the other four villages, referred to as the 'daily' group, were recruited at the same time. These women had free access to Fe tablets from the health-care services following government policy that pregnant women should receive $90-120$ Fe plus folic acid tablets, containing $60 \mathrm{mg} \mathrm{Fe}$ as ferrous sulfate and $250 \mu \mathrm{g}$ folic acid. Tablet intake in this group was not supervised because this was an effectiveness trial comparing the weekly, supervised Fe supplementation to the current programme. Adherence of tablet intake was assessed through interview during a postnatal home visit which revealed that the median tablet intake was fifty while only $17 \%$ of the subjects took more than ninety tablets (Muslimatun et al. 2001).

\section{Biochemical measures}

At approximately 4 months after delivery, non-fasting venous blood samples were taken from infants (approximately $2 \mathrm{ml}$ ) and women (approximately $5 \mathrm{ml}$ ) and collected in tubes without anticoagulant between 09.00 and 12.00 hours. It was not possible to obtain blood from all subjects, owing to maternal refusal and, in some cases, because the amount of blood obtained from infants or women was insufficient for all analyses. Blood samples of women had also been taken at enrolment (about 18 weeks of gestation) and near term (about 35 weeks of gestation). Haemoglobin was determined using the cyanmethemoglobin method (Test 3317; Merck, Darmstadt, Germany) at the Nutrition Research and Development Centre Laboratory, Bogor. For serum ferritin, soluble transferrin receptor (sTfR) and retinol analyses, blood was allowed to clot before it was placed in a cool box with cooling elements for transport to the laboratory in Bogor. Blood samples were centrifuged at $3000 \mathrm{~g}$ for $10 \mathrm{~min}$ at room temperature and serum was distributed among three vials. Serum was kept at $-20^{\circ} \mathrm{C}$ for 1 month and subsequently at $-79^{\circ} \mathrm{C}$. All analyses were carried out within 1 year of blood collection.

Serum ferritin was analysed by enzyme immunoassay (commercial kit, IMX System, Abbott, Abbott Park, IL, USA) at the Seameo Tropmed laboratory, Jakarta. Duplicate analyses were performed for $15 \%$ of the samples and the estimated variability was $0.8 \mu \mathrm{g} / \mathrm{l}$. The between-day $\mathrm{CV}$ of a pool of serum $(27 \cdot 8 \mu \mathrm{g} / \mathrm{l})$ and three control sera provided by the assay manufacturer with a low $(20 \mu \mathrm{g} / \mathrm{l})$, medium $(150 \mu \mathrm{g} / \mathrm{l})$, and high $(400 \mu \mathrm{g} / \mathrm{l})$ concentration of ferritin was $4.0,4.4,4.7$ and $4.9 \%$ respectively. Serum sTfR was analysed by immunoturbidimetric assay (IDeA sTfR-IT; Orion Diagnostica, Espoo, Finland) as described by Suominen et al. (1999) on the SMS Dimension (Dade/Behring, Wilmington, DE, USA) at Stichting Huisartsenlaboratorium Oost in Velp, the Netherlands. Duplicate analyses were performed for $10 \%$ of the samples and the estimated variability was $0.06 \mathrm{mg} / \mathrm{l}$. Between-day $\mathrm{CV}$ of control sera with a low $(1.38 \mathrm{mg} / \mathrm{l})$ and high $(5.66 \mathrm{mg} / \mathrm{l})$ concentration of sTfR was 2.5 and $3.6 \%$ respectively. Serum retinol was analysed by HPLC at the Division of Human Nutrition and Epidemiology, Wageningen University. Duplicate analyses were performed for $10 \%$ of the samples and the estimated variability was $0.05 \mu \mathrm{mol} / \mathrm{l}$. The between-day $\mathrm{CV}$ was $7.4 \%$.

\section{Anthropometry}

Weight and length of the newborn were measured by two of the authors (M.K.S. and S.M.) at the time of the postnatal home visit. At approximately 4 months after birth, two pairs of trained field assistants measured the weight and length of infants when their mothers paid the monthly visit to the health service post (Posyandu). Weight was measured to the nearest $50 \mathrm{~g}$ by using a baby-weighing scale (Misaki, Japan), which was periodically checked for its accuracy by a calibration weight. Recumbent length was measured to the nearest $0 \cdot 1 \mathrm{~cm}$ by using a wooden length board (Seameo Tropmed). Infants were measured with light clothing. At the time of blood collection, the body weight of the mothers was measured to the nearest $0.1 \mathrm{~kg}$ by using a UNICEF electronic weighing scale (model 890; SECA, Hamburg, Germany) and mid-upper arm circumference was measured to the nearest $0 \cdot 1 \mathrm{~cm}$ by using a plastic measuring tape. At enrolment, the height of the mothers had been measured to the nearest $0 \cdot 1 \mathrm{~cm}$ using a standing height measurement microtoise.

\section{Infant health}

Physicians from the community health centre (Puskesmas) examined the general health of the infants before blood sampling. Signs and symptoms examined were: running nose; fever; cough; upper respiratory tract infection; diarrhoea; skin disease, such as nappy rash and dermatitis; 
ear discharge. Besides the individual categories, the term 'sick' was defined as having at least one of the signs or symptoms mentioned above. Medical treatment was provided when necessary. At the time of the anthropometric assessment, the field assistants interviewed the mothers to assess whether they were still breast-feeding.

\section{Data analysis}

Normality of data distribution was checked by visual evaluation using a histogram with a normal curve. Serum ferritin and sTfR concentrations were not normally distributed; therefore these data were logarithmically transformed and reported as mean with $95 \%$ CI. In the analyses the weekly vitamin A plus Fe group was compared with the weekly Fe group to evaluate the effect of vitamin A supplementation. In addition, the weekly $\mathrm{Fe}$ group was compared to the daily group to evaluate the different $\mathrm{Fe}$ supplementation regimes. Differences in age, anthropometric and biochemical variables between groups were evaluated by independent $t$ test. ANOVA was used to evaluate differences between groups or genders, correcting for gender or group and age. Differences in proportions were evaluated by $\chi^{2}$ test. Trends in biochemical variables of infants by age were evaluated using linear regression. Association of parameters of biochemical status within infants and between infants and their mothers was estimated by the Pearson correlation coefficient. To establish the determinants of infant serum ferritin and retinol concentrations stepwise multiple linear regression was applied. Because the weekly Fe and daily groups did not differ with regard to anthropometric and biochemical variables, groups were defined as having vitamin A supplementation (1) or not (0), i.e. weekly vitamin A plus Fe group, 1; weekly Fe group, 0; daily group, 0 . Results did not change if we included the three groups as two dummy variables. Initially, variables of mothers during pregnancy, mothers at about 4 months postpartum and infants were included in the model. However, analysis revealed that association between maternal variables during pregnancy and infant variables was poor. Therefore, it was decided to include only variables of mothers at about 4 months postpartum and infants in the model. Variables of infants included in both models were age at the time of blood collection, gender, neonatal weight, weight at approximately 4 months of age, and haemoglobin, serum ferritin, serum sTfR and serum retinol concentrations. Variables of mothers included in both models were haemoglobin, serum ferritin, serum sTfR and serum retinol concentrations, and weight at about 4 months postpartum and height. Prevalence of upper respiratory tract infection was included in the model for serum retinol concentrations. Neonatal length and length at about 4 months of age were not included in the model because they were highly correlated with neonatal weight and weight at about 4 months of age respectively $(r>0 \cdot 8)$. Also, maternal mid-upper arm circumference was not included because it was highly correlated with maternal weight at about 4 months postpartum $(r>0 \cdot 8)$. Variables that were found to be significantly associated with the dependent variable in the stepwise multiple regression analysis were entered again in a model for each dependent variable and are presented. The SPSS software package (Windows version 7.5.2; SPSS Inc., Chicago, IL, USA) was used for all statistical analyses and a $P$ value of $<0.05$ was considered as significant.

\section{Results}

Women were recruited in six rounds from November 1997 until May 1998, and blood samples for the postpartum assessment were taken between August 1998 and February 1999. From enrolment during pregnancy until approximately 4 months after delivery (mean 3.7 (1.9-6.3) months), twenty-two (18\%), twenty (17\%) and twenty $(16 \%)$ mothers and infants dropped out in the weekly vitamin A and Fe group, weekly Fe group and daily group respectively. Drop-out did not differ among groups and was not related to the gender of the infants. Of the infants eligible for the assessment at about 4 months of age, twentyeight $(28 \%)$, twenty-five $(25 \%)$ and twenty-nine $(28 \%)$ in the weekly vitamin $\mathrm{A}$ and $\mathrm{Fe}$, weekly $\mathrm{Fe}$ and daily groups respectively did not provide a blood sample or did not attend the assessment. We present data of infants ( $n$ 222) from whom sufficient blood was drawn for the assessment of haemoglobin concentration, and their mothers (Fig. 1). Age, parity, anthropometric and biochemical variables of mothers and gender and anthropometric variables of infants either at the postnatal visit (measured $n 326$ ) or at about 4 months of age (measured $n$ 276) did not significantly differ (corrected for age) between subjects included or excluded (data not shown). However, infants for whom data are reported had higher neonatal length than infants for whom data are not reported $(49.6(\operatorname{SE~} 0.2) \mathrm{cm}, n 222 v .48 .9$ (SE 0.2) $\mathrm{cm}, n 80 ; P<0 \cdot 05)$.

Age and gender of infants were similar in all groups (Table 1). Infants in the weekly vitamin A and Fe group had higher serum retinol concentrations than the infants in the weekly Fe group (Table 1). Serum retinol concentrations did not differ between the weekly $\mathrm{Fe}$ and daily groups. The proportion of infants with a serum retinol concentration $\leq 0.35 \mu \mathrm{mol} / \mathrm{l}$ was 3,11 and $20 \%$ and with a serum retinol concentration $\leq 0.70 \mu \mathrm{mol} / \mathrm{l}$ was 71,84 and $78 \%$ in the weekly vitamin $\mathrm{A}$ and $\mathrm{Fe}$, weekly $\mathrm{Fe}$ and daily groups respectively.

Fe status, length and weight of infants did not differ between the weekly groups or between the weekly Fe group and the daily group (Table 1). The proportion of infants with a haemoglobin concentration $<100 \mathrm{~g} / \mathrm{l}$ and $<110 \mathrm{~g} / \mathrm{l}$ was similar in all groups, 29 and $68 \%$ respectively while the lowest value was $83 \mathrm{~g} / \mathrm{l}$. Only three infants had a serum ferritin concentration $<12 \mu \mathrm{g} / \mathrm{l}$. Serum ferritin and sTfR concentrations of infants were inversely correlated $(r-0.420, P<0.01)$ in all groups. Fe status and serum retinol concentrations of mothers and infants did not differ between mothers in the daily group who had taken less than fifty tablets and those who had taken more than fifty tablets during pregnancy.

Serum ferritin concentrations decreased (Fig. 2) while haemoglobin $(r \quad 0 \cdot 173)$ and serum sTfR concentrations ( $r$ 0.293) increased significantly $(P<0 \cdot 01)$ with age. Serum retinol concentrations did not change with age. Girls had a better Fe status, defined by higher serum ferritin and lower 
Vitamin A and iron status in Indonesian infants

serum sTfR concentrations, than boys. However, boys had a higher serum retinol concentration and were longer and heavier than girls (Table 1).

At about 4 months postpartum, Fe status, serum retinol concentration and anthropometric variables of mothers did not differ between the weekly groups or between the weekly Fe group and the daily group (Table 2). At approximately 4 months postpartum, serum retinol concentrations of mothers and infants were correlated $(r 0.374, P<0.01)$ in all groups. Haemoglobin concentrations of mothers and infants were positively correlated $(r 0 \cdot 248, P<0 \cdot 01)$, but if evaluated per group this reached significance only in the weekly vitamin $\mathrm{A}$ and $\mathrm{Fe}$ group and the daily group.

Maternal serum retinol concentrations at enrolment and infant serum retinol concentrations were positively correlated in the vitamin $\mathrm{A}$ and $\mathrm{Fe}$ group, weekly $\mathrm{Fe}$ group and the daily group $(r 0.127, \mathrm{NS} ; r 0 \cdot 288, P<0.05$; and $r 0.438, P<0.01$ respectively). None of the variables of Fe status of mothers during pregnancy was correlated with infant nutritional status. Also, when comparing anaemic (haemoglobin concentration $<110 \mathrm{~g} / \mathrm{l}$ ) with non-anaemic mothers or comparing mothers with serum ferritin concentration $<12 \mu \mathrm{g} / \mathrm{l}$ with those $\geq 12 \mu \mathrm{g} / \mathrm{l}$, no differences in nutritional status of infants were found.

Neonatal weight and length of infants were similar in all groups: $3 \cdot 18$ (SD 0.50$) \mathrm{kg}$ and $49 \cdot 6(\mathrm{SD} 2 \cdot 3$ ) cm respectively. The time between birth and measurement of neonatal weight and length (7.3 (SD 6.3) d) varied largely due to inadequate communication and difficulty in reaching the subjects. Only $20 \%$ of the infants were reached within $72 \mathrm{~h}$, measuring $3.01 \mathrm{~kg}$ and $48.6 \mathrm{~cm}$, and $63 \%$ were reached within $7 \mathrm{~d}$, measuring $3.07 \mathrm{~kg}$ and $49.0 \mathrm{~cm}$.

A general health check was obtained from 217 of the 222 infants. Data could not be obtained from five infants because of the temporary absence of the physician. The proportion of infants with various signs and symptoms of disease were (\%): running nose, 36 ; fever, 7 ; cough, 8 ; upper respiratory tract infection, 5; diarrhoea, 4; skin diseases such as nappy rash and dermatitis, 24; ear discharge, 2; sick (by definition having one or more signs or symptoms of disease), 56. Prevalence of these signs and symptoms and the proportion sick were similar in all groups. The serum retinol

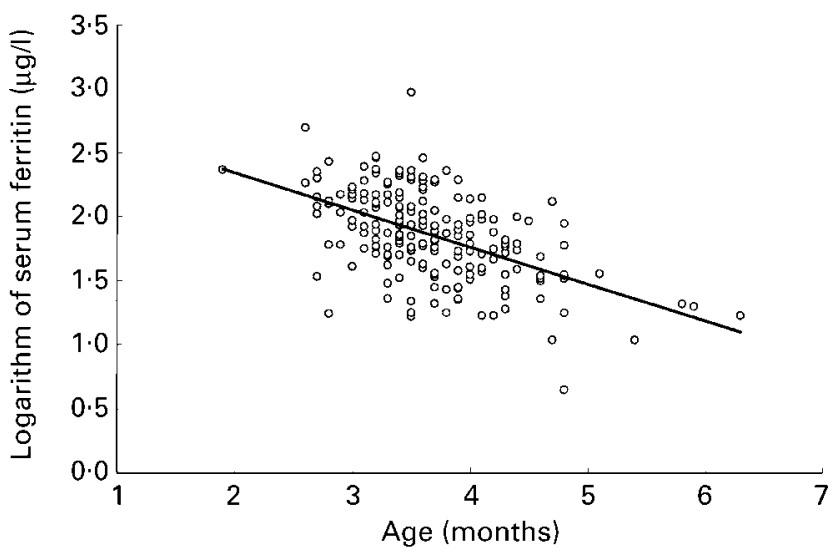

Fig. 2. Relationship between serum ferritin concentration and age of infants $(r-0.520 ; P<0.01)$. 
Table 2. Biochemical and anthropometric characteristics of mothers at approximately 4 months postpartum who had been supplemented with two tablets weekly each containing $60 \mathrm{mg}$ ferrous sulfate and $250 \mu \mathrm{g}$ folic acid ('iron') with or without 2400 retinol equivalent vitamin A. The 'daily' group had free access to iron tablets from the Indonesian governmental health services

(Mean values with their standard errors, or geometric mean values with $95 \% \mathrm{Cl}$ )

\begin{tabular}{|c|c|c|c|c|c|c|c|c|c|c|c|c|}
\hline & \multicolumn{4}{|c|}{ Vitamin A+iron } & \multicolumn{4}{|c|}{ Iron } & \multicolumn{4}{|c|}{ Daily } \\
\hline & $n$ & Mean & SE & $95 \% \mathrm{Cl}$ & $n$ & Mean & SE & $95 \% \mathrm{Cl}$ & $n$ & Mean & SE & $95 \% \mathrm{Cl}$ \\
\hline Haemoglobin (g/l) & 71 & $118 \cdot 8$ & 1.4 & & 74 & $120 \cdot 4$ & 1.6 & & 74 & $118 \cdot 7$ & 1.5 & \\
\hline Serum ferritin $(\mu \mathrm{g} / \mathrm{l})$ & 71 & $12 \cdot 3$ & & $9 \cdot 5,15 \cdot 8$ & 75 & $10 \cdot 8$ & & $8 \cdot 5,13 \cdot 7$ & 73 & 14.5 & & $11.5,18.2$ \\
\hline Serum sTfR (mg/l) & 69 & 2.07 & & $1 \cdot 90,2 \cdot 26$ & 74 & 2.04 & & $1.86,2.23$ & 73 & 1.99 & & $1 \cdot 82,2 \cdot 17$ \\
\hline Serum retinol $(\mu \mathrm{mol} / \mathrm{l})$ & 71 & $1 \cdot 14$ & 0.04 & & 73 & $1 \cdot 11$ & 0.05 & & 71 & 1.03 & 0.05 & \\
\hline Weight $(\mathrm{kg})$ & 72 & $46 \cdot 8$ & 0.7 & & 76 & $46 \cdot 8$ & 0.7 & & 74 & $47 \cdot 4$ & 0.8 & \\
\hline MUAC (cm) & 72 & $24 \cdot 3$ & 0.3 & & 76 & $24 \cdot 6$ & 0.2 & & 74 & $25 \cdot 1$ & 0.3 & \\
\hline Height $(\mathrm{cm})$ & 72 & $149 \cdot 1$ & 0.6 & & 76 & $149 \cdot 0$ & $0 . \overline{5}$ & & 74 & $149 \cdot 0$ & 0.6 & \\
\hline
\end{tabular}

sTfR, soluble transferrin receptor; MUAC, mid-upper arm circumference.

concentration of infants with upper respiratory tract infection $(0.42$ (SE 0.04$) \mu \mathrm{mol} / \mathrm{l} ; n$ 11) was lower $(P<0.01)$ than that of infants without $(0.58$ (SE 0.01$)$ $\mu \mathrm{mol} / \mathrm{l} ; n$ 167). All infants with upper respiratory tract infection had a serum retinol concentration $<0.70 \mu \mathrm{mol} / 1$. Haemoglobin concentrations were consistently lower in infants with running nose, fever, cough, upper respiratory tract infection, diarrhoea, skin diseases and ear discharge. Infants defined as sick had a haemoglobin concentration $3.3 \mathrm{~g} / 1$ less than their healthy counterparts $(P<0 \cdot 01$, corrected for age). Serum sTfR and ferritin concentrations did not differ significantly between infants with or without any sign or symptom, after correction for sex and age, except that infants with skin diseases had higher $(P<0.05)$ serum ferritin concentrations $(89 \cdot 4 ; 95 \%$ CI $71 \cdot 3,112 \cdot 1)$, than those without $(68 \cdot 7 ; 95 \%$ CI $60 \cdot 5,78)$.

Determinants of serum retinol and ferritin concentrations in infants were evaluated by multiple regression analysis and are presented in Table 3. Age, neonatal weight and gender were found to be the strongest determinants of serum ferritin concentrations. Serum retinol concentrations of mothers at approximately 4 months postpartum, upper respiratory tract infection and vitamin A supplementation showed the strongest association with serum retinol concentrations in infants. Serum retinol concentrations and weight of infants were also associated.

\section{Discussion}

The present study shows that vitamin A supplementation during pregnancy benefited serum retinol concentrations of infants at approximately 4 months of age. This is consistent with our finding that mothers in the weekly vitamin $\mathrm{A}$ and Fe group maintained their serum retinol concentrations near term in contrast to mothers in the weekly Fe group, where levels decreased (Muslimatun et al. 2001). Our finding is also in line with the study of Katz et al. (2000), showing that weekly supplementation with $7000 \mathrm{RE}$ vitamin A of Nepalese women before and during pregnancy increased serum retinol concentrations in their infants at 3 months of age.

The difference in serum retinol concentrations of the infants in our present study could have resulted from differences in the vitamin A stores built up during gestation, from differences in retinol concentrations in breast milk, or both (Underwood, 1994; Azaïs-Braesco \& Pascal, 2000). It is not yet known to what extent vitamin $\mathrm{A}$ is transferred via the placenta (Azaïs-Braesco \& Pascal, 2000); however, the vitamin A status of pregnant women and that of their newborn infants are associated (Shah \& Rajalakshmi, 1984; Shah et al. 1987). In addition, in an intervention study, Panth et al. (1990) showed that vitamin A supplementation of pregnant women increased cord levels of vitamin A. A

Table 3. Determinants of serum ferritin and retinol concentrations in infants from all groups at approximately 4 months of age, by stepwise multiple regression analysis

\begin{tabular}{|c|c|c|c|c|}
\hline & Coefficient (b) & SE & $P$ value & $R^{2}$ \\
\hline Serum ferritin concentration (logarithm) $(\mu \mathrm{g} / \mathrm{l})(n 172)$ & & & & 0.466 \\
\hline Age of infant at blood drawing (months) & -0.200 & 0.032 & 0.000 & \\
\hline Neonatal weight $(\mathrm{kg})$ & 0.194 & 0.041 & 0.000 & \\
\hline Gender $($ boy $=0$, girl $=1)$ & 0.124 & 0.040 & 0.002 & \\
\hline Serum sTfR concentration of infant (logarithm) $(\mathrm{mg} / \mathrm{l})$ & -0.560 & $0 \cdot 197$ & 0.005 & \\
\hline Haemoglobin concentration of infant $(\mathrm{g} / \mathrm{l})$ & -0.006 & 0.002 & 0.008 & \\
\hline Height of mother $(\mathrm{cm})$ & -0.012 & 0.004 & 0.002 & \\
\hline Serum retinol concentration $(\mu \mathrm{mol} / \mathrm{l})(n 168)$ & & & & 0.351 \\
\hline Serum retinol concentration of mother $(\mu \mathrm{mol} / \mathrm{l})$ & $0 \cdot 161$ & 0.031 & 0.000 & \\
\hline Upper respiratory tract infection (not present $=0$, present $=1$ ) & -0.152 & 0.051 & 0.003 & \\
\hline Vitamin $A$ supplementation (no vitamin $A=0$, vitamin $A=1$ ) & 0.071 & 0.024 & 0.004 & \\
\hline Haemoglobin concentration of infant $(\mathrm{g} / \mathrm{l})$ & 0.004 & 0.001 & 0.005 & \\
\hline Infant weight at approximately 4 months of age $(\mathrm{kg})$ & 0.042 & 0.015 & 0.006 & \\
\hline Serum sTfR concentration of infant (logarithm) (mg/l) & $0 \cdot 266$ & $0 \cdot 144$ & 0.021 & \\
\hline
\end{tabular}

sTfR, soluble transferrin receptor. 
single dose of 60000 or $90000 \mathrm{RE}$ to lactating women increased their breast milk levels and improved infant vitamin A status even up to 6-8 months after supplementation (Stoltzfus et al. 1993; Rice et al. 1999). Although women in our present study were supplemented weekly during pregnancy the amount of vitamin A given (20 weeks $\times 4800 \mathrm{RE}=96000 \mathrm{RE}$ ) as well as the difference in serum retinol concentrations of infants were comparable (Stoltzfus et al. 1993; Rice et al. 1999). In addition, all infants but one were breast-fed and not given vitamin A-rich foods (data not shown). Therefore, we can assume that they depended on their stores and breast milk intake for their vitamin A supply.

Vitamin A supplementation did not affect infant $\mathrm{Fe}$ status, which is not surprising considering the small increase in haemoglobin and decrease in serum ferritin concentrations in their mothers during pregnancy (Muslimatun et al. 2001). Nutritional status of infants in the weekly $\mathrm{Fe}$ group was similar to that of infants in the daily group. This is in line with our finding that, in terms of improving the Fe status of mothers during pregnancy, supervised weekly $\mathrm{Fe}$ supplementation performed no better and no worse than the national programme (Muslimatun et al. 2001). Infant and maternal Fe status were not associated except for an association of haemoglobin concentrations of mothers at approximately 4 months postpartum and infants. The relatively small range of maternal indicators of Fe status and amount of Fe taken during pregnancy, as compared to a placebo-controlled study in Niger in which pregnant women were supplemented with $100 \mathrm{mg} \mathrm{Fe} / \mathrm{d}$ (Preziosi et al. 1997), may explain the lack of a relationship with infant Fe status.

Infants are born with low reserves of vitamin A, even if their mothers have an adequate vitamin A status (Olson et al. 1984; Underwood, 1994). Therefore, a cut-off level of $0.35 \mu \mathrm{mol} / \mathrm{l}$ for infants after 1 month of age has been proposed (Lindblad et al. 1998). Serum retinol concentrations of our infants were low but consistent with values in Bangladeshi, Indonesian and Zambian infants (Rahman et al. 1996; Hautvast et al. 1998; Hadi et al. 2000), although in the last study only $1 \%$ had serum retinol concentrations $<0.35 \mu \mathrm{mol} / 1$. In the present study $3 \%$ of infants from mothers supplemented with vitamin A had levels $<0.35 \mu \mathrm{mol} / 1$ as compared to $>10 \%$ in the other two groups. It would be useful to compare serum retinol concentrations of our infants with those from developed countries, but unfortunately we are not aware of any publications reporting such data. The high proportion of infants with serum retinol concentrations $\leq 0.70 \mu \mathrm{mol} / \mathrm{l}$ would indicate this population as having a severe public health problem (World Health Organization, 1996), although it should be taken into account that these criteria are based on children aged 6-71 months.

Results reported from various studies on the effect of vitamin A on growth of children are not consistent (Allen, 1994). However, vitamin A supplementation has been found to improve the growth of children in an area with vitamin A deficiency (Muhilal et al. 1988) and of children with xerophthalmia (West et al. 1997). The association between weight and serum retinol concentrations suggests that vitamin A plays a role in growth, but probably the increase in serum retinol concentration was too small to have a significant effect. Supplementation of vitamin A has been shown to reduce the duration of respiratory tract infection (Rahman et al. 1996). However, the negative association between serum retinol concentrations and respiratory tract infection might also be a consequence of infection-induced changes in nutrient transport (Stephensen \& Gildengorin, 2000).

Values of parameters of Fe status we have reported are normal for infants of these ages (Siimes et al. 1979). Serum ferritin concentration as an indicator of $\mathrm{Fe}$ status has been found to decrease with age and to be determined by gender and neonatal weight (Wharf et al. 1997). Although half of the mothers were anaemic or Fe deficient during pregnancy (Muslimatun et al. 2001), it seems that their infants had sufficient Fe status, at least until 4 months of age. We do not know to what extent serum ferritin concentrations of the infants in the present study were influenced by infection. Signs and symptoms of disease, except for skin disease, did not affect the serum ferritin concentration of infants, but we did not monitor infection, for example by measuring serum C-reactive protein concentrations. However, concentrations of sTfR provide a quantitative measure of $\mathrm{Fe}$ status that is not affected by infection (Suominen et al. 1999). In general, sTfR concentrations in our infants were low, which is indicative of an adequate $\mathrm{Fe}$ status, and only four infants had concentrations higher than reported reference values for children of 6 months to 2 years $(1.48-3.51 \mathrm{mg} / \mathrm{l}$; Suominen et al. 1999). The strong inverse correlation of concentrations of serum ferritin and sTfR also suggests that the high serum ferritin values were mostly a reflection of high stores (Virtanen et al. 1999).

In conclusion, in a population with marginal vitamin A deficiency, weekly supplementation of women during pregnancy with $4800 \mathrm{RE}$ vitamin $\mathrm{A}$ in the presence of concurrent Fe supplementation benefits the vitamin A status but not Fe status, length or weight of their infants. Fe status of infants at approximately 4 months of age was considered sufficient irrespective of the supplementation regime. The difference in serum retinol levels between infants from vitamin A-supplemented pregnant mothers and their counterparts was similar to that found in studies that provided supplementation to mothers during lactation (Stoltzfus et al. 1993; Rice et al. 1999). Therefore, supplementation during pregnancy could be an alternative or an addition to supplementation during lactation and has the advantage that it can be implemented in the existing $\mathrm{Fe}$ supplementation programme. However, considering the large proportion of infants with serum retinol concentration $\leq 0.70 \mu \mathrm{mol} / 1$, we need to investigate the relevance of marginal serum retinol concentrations further in infants younger than 6 months, and whether it is necessary to increase vitamin A intake during infancy.

\section{Acknowledgements}

We are grateful to all participants, field workers, midwives and medical doctors of Leuwiliang for their contribution to this project. We are especially thankful to Bapak Nurdin Hadiat for his expertise and in particular for his careful drawing of blood. We thank the heads of health centres for providing the facilities during data collection. This work 
was supported by the Netherlands Organisation for Scientific Research-Netherlands Foundation for the Advancement of Tropical Research (NWO-WOTRO) (WV 93-280) and the Neys-van Hoogstraten Foundation (IN 114), The Netherlands and the German Agency for Technical Co-operation (GTZ)/South East Asian Ministers of Education Organisation, Tropical Medicine (SEAMEO TROPMED), Indonesia.

\section{References}

Administrative Committee on Coordination/Sub-Committee on Nutrition (2000) Fourth Report on the World Nutrition Situation. Nutrition Throughout the Life Cycle, Geneva: Administrative Committee on Coordination/Sub-Committee on Nutrition in collaboration with International Food Policy Research Institute.

Allen LH (1994) Nutritional influences on linear growth: a general review. European Journal of Clinical Nutrition 48, 75S-89S.

Allen LH (2000) Anemia and iron deficiency: effects on pregnancy outcome. American Journal of Clinical Nutrition 71, $1280 \mathrm{~S}-1284 \mathrm{~S}$.

Azaïs-Braesco V \& Pascal G (2000) Vitamin A in pregnancy: requirements and safety limits. American Journal of Clinical Nutrition 71, 1325S-1333S.

Frongillo EA Jr (1999) Symposium: Causes and etiology of stunting. Introduction. Journal of Nutrition 129, 529S-530S.

Hadi H, Stoltzfus RJ, Dibley MJ, Moulton LH, West KPJ, Kjolhede CL \& Sadjimin T (2000) Vitamin A supplementation selectively improves the linear growth of Indonesian preschool children: results from a randomized controlled trial. American Journal of Clinical Nutrition 71, 507-513.

Hautvast JL, Tolboom JJ, West CE, Kafwembe EM, Sauerwein RW \& van Staveren WA (1998) Malaria is associated with reduced serum retinol levels in rural Zambian children. International Journal for Vitamin and Nutrition Research $\mathbf{6 8}$, 384-388.

Katz J, West KPJ, Khatry SK, Pradhan EK, LeClerq SC, Christian P, Wu LS-F, Adhikari RK, Shrestha SR \& Sommer A (2000) Maternal low-dose vitamin A or $\beta$-carotene supplementation has no effect on fetal loss and early infant mortality: a randomized cluster trial in Nepal. American Journal of Clinical Nutrition 71, 1570-1576.

Kosen S, Herman S \& Schultink W (1998) An overview of studies on iron deficiency in Indonesia. Nutrition Research 18, $1935-1941$

Lindblad BS, Patel M, Hamadeh M, Helmy N, Ahmad I, Dawodu A \& Zaman S (1998) Age and sex are important factors in determining normal retinol levels. Journal of Tropical Pediatrics 44, 96-99.

Mejia LA \& Chew F (1988) Hematological effect of supplementing anemic children with vitamin A alone and in combination with iron. American Journal of Clinical Nutrition 48, 595-600.

Muhilal, Permeisih D, Idjradinata YR, Muherdiyantiningsih \& Karyadi D (1988) Vitamin A-fortified monosodium glutamate and health, growth, and survival of children: a controlled field trial. American Journal of Clinical Nutrition 48, 1271-1276.

Muslimatun S, Schmidt MK, Schultink W, West CE, Hautvast JGAJ, Gross R \& Muhilal (2001) Weekly supplementation with iron and vitamin A during pregnancy increases hemoglobin concentration but decreases serum ferritin concentration in Indonesian pregnant women. Journal of Nutrition 131, 85-90.

Nokes C, Van den Bosch C \& Bundy DAP (1998) The effects of iron deficiency and anemia on mental and motor performance, educational achievement, and behavior in children. A Report of the International Nutritional Anemia Consultative Group. Washington, DC: International Life Science Institute.

Olson JA, Gunning DB \& Tilton RA (1984) Liver concentrations of vitamin A and carotenoids, as a function of age and other parameters, of American children who died of various causes. American Journal of Clinical Nutrition 39, 903-910.

Ortega RM, Andres P, Martinez RM \& Lopez-Sobaler AM (1997) Vitamin A status during the third trimester of pregnancy in Spanish women: influence on concentrations of vitamin A in breast milk. American Journal of Clinical Nutrition 66, $564-568$.

Panth M, Shatrugna V, Yasodhara P \& Sivakumar B (1990) Effect of vitamin A supplementation on haemoglobin and vitamin A levels during pregnancy. British Journal of Nutrition 64, 351-358.

Preziosi P, Prual A, Galan P, Daouda H, Boureima H \& Hercberg S (1997) Effect of iron supplementation on the iron status of pregnant women: consequences for newborns. American Journal of Clinical Nutrition 66, 1178-1182.

Rahman MM, Mahalanabis D, Alvarez JO, Wahed MA, Islam MA, Habte D \& Khaled MA (1996) Acute respiratory infections prevent improvement of vitamin A status in young infants supplemented with vitamin A. Journal of Nutrition 126, 628-633.

Rice AL, Stoltzfus RJ, de-Francisco A, Chakraborty J, Kjolhede CL \& Wahed MA (1999) Maternal vitamin A or beta-carotene supplementation in lactating Bangladeshi women benefits mothers and infants but does not prevent subclinical deficiency. Journal of Nutrition 129, 356-365.

Roodenburg AJ, West CE, Hovenier R \& Beynen AC (1996) Supplemental vitamin A enhances the recovery from iron deficiency in rats with chronic vitamin A deficiency. British Journal of Nutrition 75, 623-636.

Scholl TO \& Hediger ML (1994) Anemia and iron-deficiency anemia: compilation of data on pregnancy outcome. American Journal of Clinical Nutrition 59, 492S-500S.

Shah RS \& Rajalakshmi R (1984) Vitamin A status of the newborn in relation to gestational age, body weight, and maternal nutritional status. American Journal of Clinical Nutrition 40, 794-800.

Shah RS, Rajalakshmi R, Bhatt RV, Hazra MN, Patel BC, Swamy NB \& Patel TV (1987) Liver stores of vitamin A in human fetuses in relation to gestational age, fetal size and maternal nutritional status. British Journal of Nutrition 58, 181-189.

Siimes MA, Saarinen UM \& Dallman PR (1979) Relationship between hemoglobin concentration and transferrin saturation in iron-sufficient infants. American Journal of Clinical Nutrition 32, 2295-2300.

Stephensen CB \& Gildengorin G (2000) Serum retinol, the acute phase response, and the apparent misclassification of vitamin A status in the third National Health and Nutrition Examination Survey. American Journal of Clinical Nutrition 72, 1170-1178. Stoltzfus RJ, Hakimi M, Miller KW, Rasmussen KM, Dawiesah S, Habicht JP \& Dibley MJ (1993) High dose vitamin A supplementation of breast-feeding Indonesian mothers: effects on the vitamin A status of mother and infant. Journal of Nutrition 123, 666-675.

Suharno D, West CE, Muhilal, Karyadi D \& Hautvast JGAJ (1993) Supplementation with vitamin A and iron for nutritional anaemia in pregnant women in West Java, Indonesia. Lancet 342, 1325-1328.

Suharno D, West CE, Muhilal, Logman MH, de-Waart FG, Karyadi D \& Hautvast JGAJ (1992) Cross-sectional study on the iron and vitamin A status of pregnant women in West Java, Indonesia. American Journal of Clinical Nutrition 56, 988-993.

Suominen P, Punnonen K, Rajamaki A, Majuri R, Hanninen V \& Irjala K (1999) Automated immunoturbidimetric method for 
measuring serum transferrin receptor. Clinical Chemistry $\mathbf{4 5}$, $1302-1305$

Underwood BA (1994) Maternal vitamin A status and its importance in infancy and early childhood. American Journal of Clinical Nutrition 59, 517S-522S.

Virtanen MA, Viinikka LU, Virtanen MK, Svahn JC, Anttila RM, Krusius T, Cook JD, Axelsson IE, Raiha NC \& Siimes MA (1999) Higher concentrations of serum transferrin receptor in children than in adults. American Journal of Clinical Nutrition 69, 256-260.

Waterlow JC \& Schürch B (1994) Causes and mechanisms of linear growth retardation. Proceedings of an I/D/E/C/G workshop held in London January 15-18, 1993. European Journal of Clinical Nutrition 48, S1-S216.

West KP Jr, LeClerq SC, Shrestha SR, Wu LS, Pradhan EK, Khatry SK, Katz J, Adhikari R \& Sommer A (1997) Effects of vitamin A on growth of vitamin A-deficient children: field studies in Nepal. Journal of Nutrition 127, 1957-1965.

Wharf SG, Fox TE, Fairweather TS \& Cook JD (1997) Factors affecting iron stores in infants 4-18 months of age. European Journal of Clinical Nutrition 51, 504-509.

World Health Organization (1996) Indicators for Assessing Vitamin A Deficiency and their Application in Monitoring and Evaluating Intervention Programmes WHO/NUT/96.10. Geneva: WHO.

World Health Organization (1998) Safe Vitamin A Dosage during Pregnancy and Lactation. Recommendations and Report of a Consultation. Geneva: WHO, Micronutrient Initiative.

Yip R (2000) Significance of an abnormally low or high hemoglobin concentration during pregnancy: special consideration of iron nutrition. American Journal of Clinical Nutrition 72, 272S-278S. 